\title{
Reviews
}

\section{Laura Wright}

\section{Milking the Zeitgeist}

Mathilde Cohen and Yoriko Otomo, eds. Making Milk: The Past, Present, and Future of our Primary Food. London: Bloomsbury, 2017. 301 pp. \$128.00 hc.

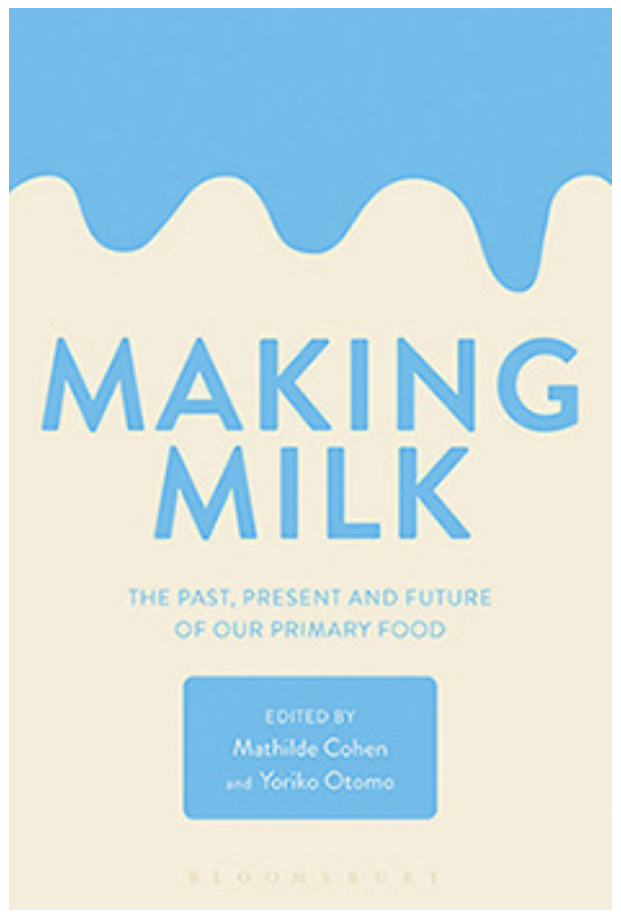

In the contemporary United States, we find ourselves in an interesting and problematic moment with regard to our relationship with, and conception of, "milk," a substance that has always been imbued with meaning beyond its status as our first food. In a December 21, 2018 article in Vox, “'Fake Milk': Why the Dairy Industry if Boiling over Plant-Based Milks," Umair Irfan explains the fight between the $\$ 35.5$ billion U.S. milk industry and the $\$ 1.6$ billion plant-based milk industry over the right to use the word "milk" on its non-dairy products. He notes that "milk has a complicated, jargonfilled standard of identity," but even so, "the dairy industry has complained for almost 20 years that the FDA hasn't policed this definition as products made from soy, almonds, cashews, rice, hemp, and oats have filled shelves in the dairy aisle." Dairy producers claim that it is unfair, for plant-based products lack the nutritional profile and taste of dairy milk but are taking advantage of the milk "brand" (Irfan). The milk 
industry in the U.S. has been losing ground and profits as non-dairy alternatives gain popularity, and even though the semantic battle has been brewing for years, the current administration's industry-friendly FDA might be willing to enforce a definition of "milk" that only covers substances produced by animals.

Further, the visual rhetoric of drinking cow's milk directly from half-gallon and gallon containers is a prominent part of the contemporary Alt-Right lexicon, which has gained visibility since the 2016 election of Donald Trump to President of the United States. The prominence of milk in the discourse of contemporary white supremacists apparently results from a supposed genetic trait more common in white people than in other groups, the ability to process and digest lactose as adults (Harmon). Despite the science behind such a trait indicating that the ability to digest lactose is not unique to white people, white supremacists'

support for milk is grounded in symbolism as much as in (pseudo-) science. On this front, the argument has historical precedent. When milk first gained prominence in America, early dairy advocates extolled its virtues to the "Aryan" population, writes historian Melanie Dupuis. As President Herbert Hoover, giving a speech in 1923, told the World's Dairy Congress, "Upon this industry, more than any other of the food industries, depends not alone the problem of public health, but there depends upon it the very growth and virility of the white races." (Moon)

Given these present realities, the essays that make up Mathilde Cohen and Yoriko Otomo's lavishly illustrated and astutely researched study Making Milk: The Past, Present, and Future of our Primary Food provide timely and important reading, showing us how "milk" has always been a fraught entity, entangled with and often inseparable from our ideas about gender, power, commodification, and cultural identity. Taken as a whole, the work constitutes a timely reading that navigates the fraught nutritive, sociopolitical, cultural, and symbolic status of milk, a food that Melanie Jackson and Esther Leslie refer to as "an ur-substance, an originary substance" (63).

In addition to the contribution of Jackson and Leslie, this collection features essays by international scholars and artists from a variety of fields, including law, literature, geography, political aesthetics, communication and media, history, media studies, sociology, art history, economics, and anthropology, all of whom grapple with the fraught and complex social, legal, political, and historical meaning of milk as food,

Laura Wright -- Milking the Zeitgeist 
mythological substance, and metaphor. In his foreword to the work, Peter J. Atkins (Emeritus, University of Durham) notes the growth in the field of milk studies since he began researching 45 years prior and since the 2010 publication of his genealogical study of milk as a commodity, Liquid Materialities. In their introduction, Cohen and Otomo likewise discuss the ways that milk has become a serious topic of study in the social sciences since the turn of the millennium. They note the importance of thinking about milk in the current moment, fraught as it is with crises of masculinity, climate change, and issues of food sovereignty. To that end, they have edited a collection that both explains and problematizes our understandings of milk, as food, as metaphor, as gendered commodity, and as legal entity.

The text is arranged in four parts. Part one, "Drinking Milk: Histories and Representations," is comprised of essays that examine the historical role of milk in several locations at various historical periods, including Chloé Maillet's examination of visual representations of milk in the Occidental Late Middle Ages, which examines "cross-species milk kinship in the Middle Ages" (8) and the ways that milk consumption was perceived during this period as capable of shaping the very essence of the consumer, particularly as mother's milk was thought to be the same substance as blood, only "whitened in utero" (9). Maillet discusses the ways that milk both signified virginity (in its associations with the cult of the Virgin Mary) and the blood of martyrs, including Christ, and she further analyses the trope of breastfeeding men (an image that appeared in paintings during the 12th through 14th centuries), as well as the transgressive nature of cross-species and adult breastfeeding as depicted in works from the 12th through 15th centuries. Carol J. Adams, whose work has long been focused on the sexual politics of feminized protein, brings to the surface the ways that animal rights and vegan activists have historically worked to expose the connections between human femaleness and the exploitation of cows for human consumption of milk. In her exploration of advertising motifs that conflate animal and human images, Adams notes that "feminized protein from other species that is sold to humans arises from a destroyed relationship between mother and child and signals our broken relationships with other animals" (23). Finally, Andrea J. Wiley explores the consumption of milk in India since independence in 1947. She claims that despite the fact that India maintains the highest level of milk production and consumption, the country has received little critical scrutiny in scholarly examinations of food. Wiley traces milk's 8000-year history in India as well as the role of cows, including their protected status, more generally. She notes that during the period after independence, milk has been associated with the strength and growth of the nation as it has become a rising world power.

Humanimalia: a journal of human/animal interface studies

Volume 10, Number 2 (Spring 2019) 
The second section, "Making Milk: Technologies and Economies," moves from historical conceptions of milk to the means of its production, the politics of labor inherent in its creation and dissemination, and the establishment of legal precedent with regard to the meaning of "milk." Melanie Jackson and Esther Leslie unpack milk's mythological and metaphorical status as both a "primal substance" that is nevertheless constantly evolving and "ever invented anew" (64) as it is separated from its source and shaped and rebranded in multiple ways - as ice cream, infant formula, or powder, for example, marketed by cartoon characters and other appealing avatars. Richie Nimmo's essay about the messy history of the creation of milking machines examines the mechanization of cow's milk, the primary milk consumed by humans, in the context of industrial factory farming. He reads milk production via various theoretical lenses Marxist, feminist, and human-animal studies - even as he provides a critique of these frameworks' tendency to "presuppose and affirm an essential or given animal subjectivity" (83). Yofi Tirosh and Yair Eldan discuss a class-action lawsuit that took place in Israel in 1995 against the dairy manufacturer Tnuva, which had put silicon in the one percent milk it sold for public consumption. Their essay focuses both on the nature of disgust, as felt by consumers who had partaken of the non-Kosher contaminated food, as well as the legal challenges inherent in compensating consumers for this disgust - a disgust linked not only to compromised milk, but also to a compromised conception of the Israeli state itself, as "milk served here as a vehicle for restating collective commitments: social, cultural, national, ethical, and commercial" (114). In the final chapter in this section, Julie P. Smith examines the contemporary practice of commercial wet-nursing and the exchange of human milk across national boundaries as a means of potentially elevating the status of breastfeeding as commodity-driven labor practice. Smith reads breastfeeding as form of women's work that is undervalued and incompatible with industrialized labor.

The third section, "Queering Milk: Male Feeding and Plant Milk," contains essays that examine the subversion of milk production's seemingly essential status as a biologically mammalian female process. Mathilde Cohen offers a "trans- or cross-species" (143) analysis of male lactation in order to trouble supposed truths about sex, gender, and parenting. Her essay demonstrates that although male lactation is possible, it is nevertheless atypical. She makes a distinction between male lactation and male breastfeeding, a process that she claims "is defined neither by milk production on the breastfeeder side nor by milk intake on the infant side" (149). Hannah Ryan chronicles Alfred W. Bosworth's invention of Similac, his work on the Boston Floating Hospital, and his extrication of himself from his achievement in 1929, once formula became a 
corporate commodity that was marketed to displace breastmilk. Further, this essay focuses on the ways that women's bodily labor is virtually invisible and recorded in the history of the creation of infant formula, even as their breastmilk and the work that they did caring for the babies that Bosworth studied were essential to his endeavor. "Plant Milk: From Obscurity to Visions of a Post-Dairy Society," by Tobias Linné and Ally McCrow-Young, traces the history of plant-based milks and the ways that the contemporary idea that such milk as nutritionally superior to dairy milk challenges powerful dairy industry propaganda machines in Europe and the U. S. that have sought to sell the idea dairy milk as synonymous with national identity. In their chapter, they "re-inscribe plant milk into the social, political, economic, and cultural history of food, primarily with a focus on the 20th and 21st centuries" (196), noting that plant milk challenges the notion of what milk is, a point that opens plant milks up to scrutiny and, as is the case in the U.S. at present, potential litigation. In the final essay in this section, Greta Gaard offers a wide-ranging theoretical exploration that engages with "milk - in its many scientific and cultural constructions - as a lens for exploration, bringing together intersections of queer ecofeminist, transgender, material feminist, postcolonial, critical animal, and critical plant studies perspectives" in order to answer the question that she repeatedly asks, "what is [milk]?" She concludes by questioning what it might mean to queer the biblical land of milk and honey, establishing it not as god-given material for human exploitation but rather a space of "trans*species" freedom and justice.

The final section, "Thinking about Plant Milk," concludes the collection by bringing the reader fully through such a "trans" experience, from initial conceptions of milk as the product of female mammalian production to a place in which we can understand "milk" - both literally and theoretically - as substance and signifier that encompass so much more. Jessica Eisen offers a posthumanist reading of milk that brings the cow back to the foreground even as it situates the cow within the broader context of the law, which codifies modern dairy farming. Mathilda Arvidsson's brief final chapter constitutes a "recipe-manifesto" for oat milk, a plant milk that Arvidsson contextualizes within her own experience of understanding the meaning of milk in order to explain "post-dairy visions and ethics" (249). Of the recipe and commentary that she provides, she concludes that "the slowness of milk-making provides us with a mode of resistance against relationships with beings we do not honor through the desire for the pure, perfecting, relational food epitomized by milk" (249). The essays in this volume serve to explore milk from a variety of perspectives, all of which nonetheless speak to one another; the essays and authors reference each other and engage in a discussion across fields and modalities; and the overall organization of the volume allows for these essays

Humanimalia: a journal of human/animal interface studies

Volume 10, Number 2 (Spring 2019) 
to be taken as a whole, as a history and social commentary, about the nature and shifting meaning of an important and enigmatic substance.

\section{Works Cited}

Atkins, Peter. Liquid Materialities. A History of Milk, Science and the Law. Routledge, 2010.

Harmon, Amy. "Why White Supremacists Are Chugging Milk (and Why Geneticists Are Alarmed)." New York Times, 17 Oct. 2018. Online. Accessed 12 Jan. 2019.

Irfan, Umair. "'Fake Milk': Why the Dairy Industry is Boiling Over Plant-Based Milks." Vox 21 Dec. 2018. Accessed 12 Jan. 2019.

Moon, Emily. "Why is Milk Being Called a White Supremacist Symbol?" Pacific Standard 24 Oct. 2018. Online. Accessed 12 Jan. 2019. 